\title{
Cytauxzoon sp. Infection in Two Free Ranging Young Cats: Clinicopathological Findings, Therapy and Follow Up
}

Serbest Dolaşan İki Genç Kedide Cytauxzoon sp. Enfeksiyonu: Klinikopatolojik Bulgular, Tedavi ve Takip

\section{Erika Carli1,2, Michele Trotta², Eliana Bianchi ${ }^{3}$, Tommaso Furlanello², Marco Caldin², Mario Pietrobelli , Laia Solano-Gallego ${ }^{4}$}

'Department of Animal Medicine, Productions and Health, University of Padua, Padua, Italy

${ }^{2}$ San Marco Veterinary Laboratory, Padua, Italy

3Piazza Bologna Veterinary Clinic, Rome, Italy

${ }^{4}$ Department of Animal Medicine and Surgery, Autonomous University of Barcelona, Barcelona, Spain

\section{ABSTRACT}

Two young brother male free-ranging domestic shorthair cats were evaluated for diarrhea. They presented with intraerythrocytic piroplasms on blood smear evaluation. Only the first cat was anemic (mild non-regenerative anemia). A partial segment of the 18S rRNA was amplified and sequenced, revealing a homology of $99 \%$ with Cytauxzoon sp. and of $93 \%$ with Cytauxzoon felis. The first cat was treated with doxycycline and imidocarb dipropionate and monitored by serial laboratory exams, resulting negative for Cytauxzoon sp. infection after the end of the therapy (follow-up period of 175 days). The second cat received the same therapy, but doxycycline was discontinued by the owner after 1 week. He was monitored for 130 days, remaining erythroparasitemic and asymptomatic. We described cases of Cytauxzoon sp. infection in domestic cats with detailed clinical data, description of two therapeutic protocols, and follow-up after treatment with opposite parasitological responses (parasitological cure versus persistence of infection). (Turkiye Parazitol Derg 2014; 38: 185-9)

Key Words: Cytauxzoon sp., cat, clinicopathological findings, therapy

Received: 03.04.2014

Accepted: 04.04.2014

\section{ÖZET}

Serbest dolaşan evcil iki genç erkek kardeş kısa tüylü kedi diyare açııından değerlendirildi. Kan yayması değerlendirmesinde intraeritrositik piroplazmaları mevcuttu. Sadece ilk kedi anemikti (hafif, rejeneratif olmayan anemi).18S rRNA'nın kısmi bir segmenti amplifiye edildi ve sekanslandı, Cytauxzoon sp. ile \%99 ve Cytauxzoon felis ile \%93'lük bir homoloji gösterdi. Birinci kedi doksisiklin ve imidokarb dipropionat ile tedavi edildi ve tedavi bitiminden sonra seri laboratuvar muayeneleri ile izlendi, Cytauxzoon sp. enfeksiyonu için negatif sonuç verdi (175 günlük takip süresi). İkinci kedi aynı tedaviyi aldı ancak doksisiklin bir hafta sonra sahibi tarafından kesildi. Eritroparazitemik ve asemptomatik kalarak 130 gün boyunca izlendi. Biz ayrıntılı klinik veriler, iki tedavi protokolünün tanımlanması ve zıt parazitolojik cevapla (kalıcı enfeksiyona karşın parazitolojik kür) tedavi sonrası takip ile birlikte evcil kedilerde Cytauxzoon sp. enfeksiyonu vakalarını tanımladık. (Turkiye Parazitol Derg 2014; 38: 185-9)

Anahtar Sözcükler: Cytauxzoon sp., kedi, klinikopatolojik bulgular, tedavi

Geliş Tarihi: 03.04.2014

Kabul Tarihi: 04.04.2014

Address for Correspondence / Yazışma Adresi: Dr. Erika Carli, San Marco Veterinary Laboratory, Via Sorio 114/c, Padua, Italy. Phone: +390498561039 E-mail: erikarli74@gmail.com DOI:10.5152/tpd.2014.3540

CCopyright 2014 Turkish Society for Parasitology - Available online at www.tparazitolderg.org

CTelif hakkı 2014 Türkiye Parazitoloji Derneği - Makale metnine www.tparazitolderg.org web sayfasından ulaşılabilir. 


\section{INTRODUCTION}

Cytauxzoonosis is a tick-transmitted protozoal disease affecting wild and domestic felids (1) caused by Cytauxzoon felis (C. felis) and reported mainly in the United States (1). A severe, often fatal disease was described in domestic felids (1), but cats surviving natural infection or infected and apparently healthy occur (2). To date, a specific treatment is not available.

Cytauxzoon sp. genetically similar to $C$. felis was identified in Pallas's cats from Mongolia, in a cat and in Iberian lynx in Spain, in a cat in France, and in a feline population from a focus in the northeastern of Italy (3-7). The majority of the Cytauxzoon sp. infected cats was apparently healthy, low-erythroparasitemic, and sporadically anemic (7). Some cases with clinical illness and fatal development were described (7). To the author's knowledge, there is limited clinical and epidemiological information about this infection in Europe.

The present case report describes clinicopathological findings, diagnosis, therapy, and follow-up in two free-ranging young cats naturally infected with Cytauxzoon sp. with opposite parasitological responses (parasitological cure versus persistence of infection).

\section{CASE REPORT}

Cat no. 1 was a 6-month-old, male, domestic shorthair that was referred to a veterinarian for diarrhea in October 2009. The cat was adopted from a colony living in Acquapendente (central Italy) (Figure 1). A massive infestation by ticks occurred in the area where he was born during the summer before his adoption. The cat had no history of vaccination and ectoparasiticide treatment. Only a corneal lesion was observed at the physical examination. No ticks or fleas were found. Toxocara sp. eggs were detected on fecal microscopic examination. Complete blood count (CBC), biochemical profile, and serum protein electrophoresis were assessed as previously described (7) at the San Marco Laboratory, Padua (Italy) within $24 \mathrm{~h}$ after the collection. CBC was performed by an automatic cell counter (ADVIA ${ }^{\circledR} 2120$, Siemens Healthcare Diagnostics, Erlangen, Germany) in conjunction with blood smear evaluation. Serial laboratory findings of cat no.1 are summarized in Table 1. Mild non-regenerative anemia, mild leukocytosis, monocytosis, and thrombocytosis were present. Intraerythrocytic piroplasms suggestive of Cytauxzoon sp., Theileria sp., or small form Babesia sp. were noted on blood smear evaluation (Figure 2). The parasitemia was classified as low-grade (7).

Deoxyribonucleic acid (DNA) extraction was performed from Ethylendiaminetetracetic acid blood by the High Pure Polymerase Chain Reaction (PCR) Template Preparation Kit (Roche Applied Science, Mannheim, Germany) in accordance with the manufacturer's protocol with some modifications (7). A fragment of the 18S rRNA gene of Piroplasmidae species of approximately 412 base pair (bp) was amplified by conventional PCR (7). Then, positive PCR samples were directly sequenced. The sequencing was performed by an Applied Biosystem 3730xl DNA Analyzer (Applied Biosystem, Carlsbad, California) on both strands by BMR Genomics srl (Padua, Italy) by using the dideoxy chain-termination method (8). The consensus sequence was compared to the sequences deposited in GenBank ${ }^{\circledR}$ using the basin local

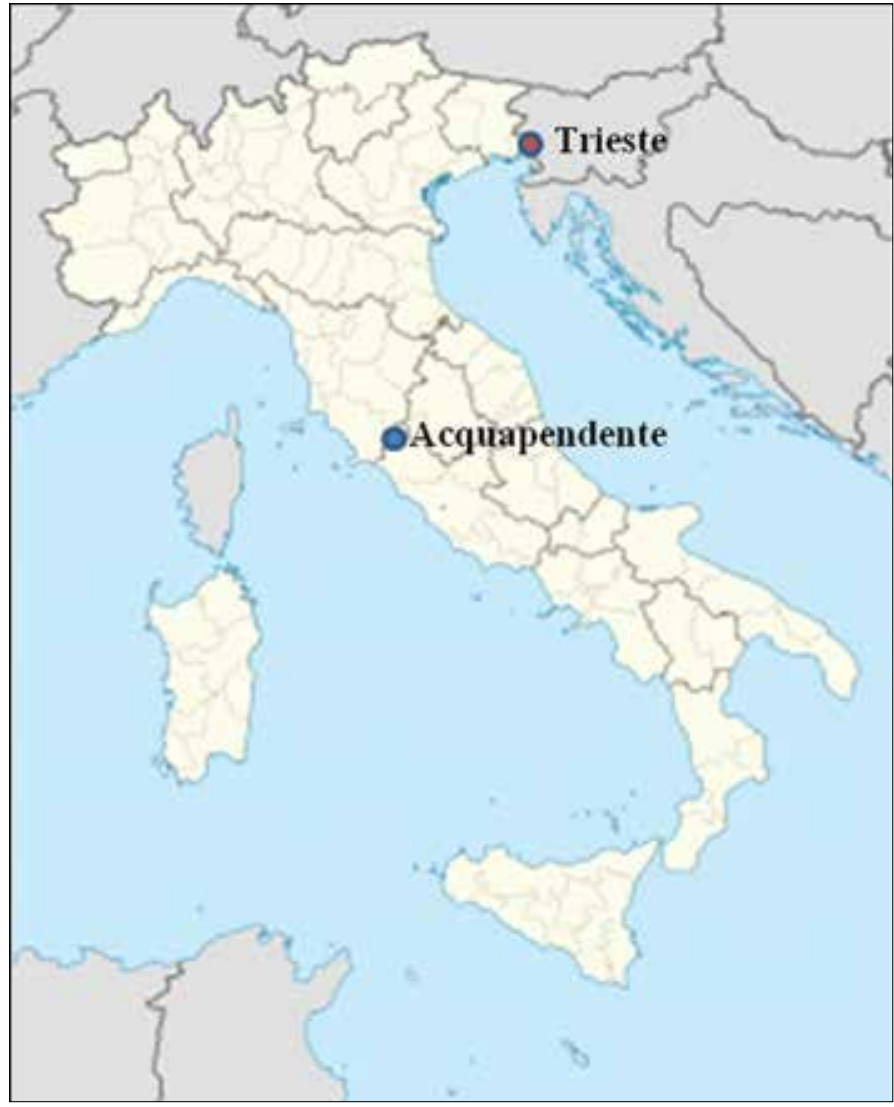

Figure 1. Geographical location of Acquapendente $\left(42^{\circ} 44^{\prime} 41^{\prime \prime} \mathrm{N}\right.$, $11^{\circ} 51^{\prime} 54^{\prime \prime} \mathrm{E}$, Viterbo) (blue spot), the little town located in the north part of the Lazio, on the border with Umbria and Tuscany (central Italy) where cats no. 1 and 2 were born and lived until the adoption (http://i.wikipedia.org/wiki/Acquapendente). Geographical location of Trieste (red spot), the town where an endemic focus of Cytauxzoon $\mathrm{sp}$. infection was described.

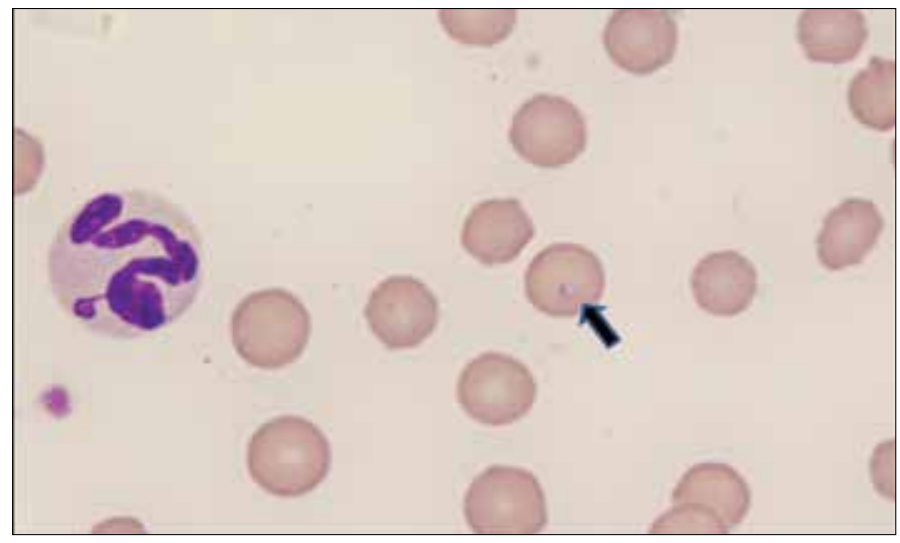

Figure 2. Cytauxzoon sp parasite inside red blood cell (arrow) in cat no. 1. in blood smear stained by the modified Wright technique (Aerospray slide stainer 7120 Delcon ${ }^{\circledR}$, 1000x). Cytauxzoon sp appears as individual, small round to oval signet ring intraerythrocytic organisms of $0.5-0.8 \mu \mathrm{m}$ of diameter with an eccentric basophilic nucleus and a lightly basophilic cytoplasm.

alignment search tool (BLAST) (http://www.nbci.nlm.nih.gov/ BLAST/). A nucleotide-nucleotide BLAST search (blastn) was performed using the default settings. The DNA sequences obtained were $99 \%$ identical to the Cytauxzoon sp. sequences 
Table 1. Serial laboratory findings for cat no. 1 during the follow up period

\begin{tabular}{|c|c|c|c|c|c|c|}
\hline & Day 1 & Day 43 & Day 57 & Day 63 & Day 87 & Day 175 \\
\hline \multicolumn{7}{|l|}{$\begin{array}{l}\text { Laboratory Parameters } \\
\text { (Reference interval) }\end{array}$} \\
\hline $\operatorname{RBC}\left(6.35-9.50 \times 10^{6} / \mu \mathrm{L}\right)$ & 5.9 & 9.01 & 8.67 & 7.21 & 8.28 & 8.93 \\
\hline Hemoglobin (9.6-14.3 g/dL) & 8.6 & 12.8 & 11.9 & 9.8 & 12 & 12.4 \\
\hline Hct (28-42.5\%) & 30.1 & 39.7 & 35.9 & 32.3 & 42.1 & 43.3 \\
\hline WBC $(5-11 \times 103 / \mu L)$ & 11.67 & 8.91 & 0.64 & 2.47 & 8.02 & 10.72 \\
\hline Segmented neutrophils $(2500-7000 / \mu \mathrm{L})$ & 6864 & 4591 & 96 & 649 & 4452 & 4601 \\
\hline Monocytes (65-250/uL) & 396 & 249 & 15 & 165 & 104 & 246 \\
\hline PLT $\left(130-430 \times 10^{3} / \mu \mathrm{L}\right)$ & 456 & 458 & 256 & 22 & 441 & 402 \\
\hline CPK (90-320 IU/L) & 130 & & & 697 & & \\
\hline ALP (19-70 IU/L) & 109 & & & 23 & & \\
\hline Total protein $(6.3-7.8 \mathrm{~g} / \mathrm{dL})$ & 6.5 & & & 6.5 & & \\
\hline Albumin $(3-4 \mathrm{~g} / \mathrm{dL})$ & 3.1 & & & 2.5 & & \\
\hline Globulin (3-4.5 g/dL) & 3.4 & & & 4 & & \\
\hline Total bilirubin $(0.14-0.26 \mathrm{~g} / \mathrm{dL})$ & 0.21 & & & 0.17 & & \\
\hline BUN (32-64 mg/dL) & 41 & & & 72 & & 47 \\
\hline Creatinine $(0.95-1.85 \mathrm{mg} / \mathrm{dL})$ & 0.91 & & & 1.09 & & 1.35 \\
\hline Glucose $(86-116 \mathrm{mg} / \mathrm{dL})$ & 99 & & & 91 & & \\
\hline Iron $(50-118 \mu \mathrm{g} / \mathrm{dL})$ & 38 & & & 209 & & \\
\hline UIBC $(130-225 \mu \mathrm{g} / \mathrm{dL})$ & 232 & & & 22 & & \\
\hline SAA $(0.1-0.5 \mu \mathrm{g} / \mathrm{mL})$ & 1.3 & & & 77.8 & & 0.1 \\
\hline$\alpha$-globulin (17.8-27.6\%) & 16.7 & & & 28.2 & & \\
\hline$\beta$-globulin (6.4-9.4\%) & 15.2 & & & 14.7 & & \\
\hline PCR results & POS & NEG & NEG & NEG & NEG & NEG \\
\hline Presence of piroplasms in blood smear & $\operatorname{POS}(+)$ & NEG & NEG & NEG & NEG & NEG \\
\hline
\end{tabular}

present in GenBank $^{\circledR}$. The highest identity was obtained with Cytauxzoon sp. 18S rDNA partial sequences reported in Italian (7), Spanish (4, 5), French (6), and Mongolian (3) wild and domestic felids. In contrast, the sequences revealed an identity of 93\% with C. felis deposited in GenBank ${ }^{\circledR}$. The new Cytauxzoon sp. nucleotide sequence was deposited in the GenBank ${ }^{\circledR}$ database with accession number KF031139. PCR analysis from the blood sample for detection of Mycoplasma haemofelis, Candidatus Mycoplasma haemominutum, Candidatus Mycoplasma turicensis (9), Bartonella henselae (10) and Leishmania infantum (11) and to serological detection of Feline Immunodeficiency Virus antibody and Feline Leukemia Virus p27 antigen performed by commercial ELISA tests (ViraCHEK ${ }^{\circledR} / F I V$ and ViraCHEK®/FeLV, Synbiotics Corporation ${ }^{\circledR}$, Exton, Pennsylvania) were negative.

Doxycycline therapy (Vibravet, Pfizer, New York, USA, 10 mg/kg/ q12h PO for 3 weeks) was instituted when piroplasms were found on blood smear evaluation. Then, imidocarb dipropionate (Carbesia, Intervet Italia, Milan, Italy, 5 mg/kg IM for two times 2 weeks apart) was administered after Cytauxzoon sp. infection confirmation by PCR and sequencing (day 14). The cat improved and was monitored for 175 days by serial CBC, biochemical profile, and serum protein electrophoresis (Table 1). Two weeks after the last imidocarb dipropionate administration (day 43), Cytauxzoon sp. was not detected by CBC and PCR analysis. On the 57th day, the cat was weak, anorectic, and seriously leukopenic (Table 1). Parvovirus infection was revealed by PCR analysis (12). Cytauxzoon sp. blood smear evaluation and PCR analysis were negative. Metronidazole (Deflamon, SPA, Milan, Italy 10 $\mathrm{mg} / \mathrm{Kg} / \mathrm{BID}, \mathrm{EV}$ ), ranitidine (Ranidil, Menarini, Florence, Italy, 2 $\mathrm{mg} / \mathrm{kg} / \mathrm{BID}, \mathrm{EV})$, and fluids were administered. Clinical and laboratory conditions improved. Cytauxzoon sp. piroplasms were not detected by blood smear evaluation and PCR analysis during the follow-up period.

Cat no. 2 belonged to the same litter of cat no. 1. He was a 7-month-old, male, domestic shorthair evaluated for diarrhea on November 2009. Fecal microscopic examination was not per- 
formed. CBC, blood smear evaluation, PCR analysis, and sequencing were done by the San Marco laboratory, and Cytauxzoon sp. infection was diagnosed. The sequence obtained was deposited in the GenBank database with accession number KF031140. Low parasitemia (7), leukocytosis with mature neutrophilia, monocytosis, and thrombocytosis were present. The instituted therapy with doxycycline (10 mg/kg/q24h PO) was discontinued by the owner after 1 week. Then, the cat was treated with imidocarb dipropionate $(5 \mathrm{mg} / \mathrm{kg}$ IM for two times 2 weeks apart). On the 130th day, a mild increase of erythrocyte number, normal leukocytic concentration, and mild thrombocytosis were observed. Aspartate aminotransferase, alanine aminotransferase, blood urea nitrogen, and creatinine were within normal limits. Other laboratory parameters were not available. The cat was clinically well.

\section{DISCUSSION}

In the present work, we described two cats with natural Cytauxzoon sp. infection demonstrated by blood smear evaluation and PCR analysis. Sequence comparison of positive samples revealed high homology with isolates from Mongolia, Spain, France, and Italy (3-7). In the present manuscript, for the first time, infection by Cytauxzoon sp. was described in cats from central Italy. In fact, Cytauxzoon sp. infection was previously reported in domestic cats only in a focus in Trieste (northeastern Italy) (7).

The cats presented with diarrhea and low parasitemia. Cat no. 1 had mild non-regenerative anemia, and cat no. 2 was not anemic. Differentials for the mild non-regenerative anemia include young age and inflammatory disease-associated anemia (13). These data were in agreement with a previous report where the majority of Cytauxzoon sp.-infected cats was apparently healthy and not anemic, showing more often subclinical infection and, rarely, signs of illness (7). In fact, both cat no. 1 and cat no. 2 demonstrated low parasitemia, with diarrhea as the only clinical sign. In cat no. 1, diarrhea could be consequent to the Toxocara sp. infestation, as observed by fecal microscopic examination. Though a fecal examination was not performed, this infestation could also be the probable cause of diarrhea in cat no. 2, as it belonged to the same litter of cat no. 1. In addition, in the follow-up period, cat no. 2 remained persistently erythroparasitemic with no evidence of illness. In agreement with this data, persistent parasitemia has been previously reported only in three Cytauxzoon sp-infected sick cats that were monitored, respectively, for 25, 288, and 49 days after diagnosis, remaining positive on blood smear and PCR analysis (7). On the contrary, C. felis infection is characterized by nonspecific clinical signs of fever, lethargy, anorexia, dehydration, icterus, pallor of mucous membrane, dyspnea, and progressive anemia (1). In contrast, wild felids more often are persistently erythroparasitemic and healthy (1). Rarely, wild felids have acute and fatal disease (14). Consequently, infection by Cytauxzoon sp. in European domestic cats seems to be more similar to $C$. felis infection in wild felids than in domestic cats. Apparently healthy and persistently parasitemic cats may serve as a reservoir for Cytauxzoon sp. infection. Accordingly, descriptions of subclinical, persistently, and naturally $C$. felis-infected domestic cats sometimes are reported in the United States (2). It could be hypothesized that these cats could serve as additional hosts for this parasite (2). The role of
Cytauxzoon sp.-infected domestic cats in the life cycle of the parasite remains unclear and has to be investigated further.

Cat no. 1 appeared to clear up the infection after a doxycycline and imidocarb dipropionate therapy, resulting in negative blood smear evaluation and PCR analysis for Cytauxzoon sp. detection during follow-up. In contrast, cat no. 2 remained erythroparasitemic, but he was treated only with imidocarb dipropionate, because doxycycline was discontinued by the owner. Moreover, two sick infected cats previously described in northeastern Italy were treated with antiprotozoan drugs without improvement (7). However, sick infected cats were not treated with a combination of doxycycline and imidocarb dipropionate. Various treatments for cytauxzoonosis by $C$. felis have been described, but to date, no antiprotozoal therapy has been demonstrated to modify the course of the disease in acutely infected cats (15). In naturally infected cats, diminazene aceturate administration led to survival in acute infection and was unable to eliminate or decrease the parasite in healthy chronic infection $(16,17)$. Imidocarb dipropionate and enrofloxacin were unsuccessfully used in asymptomatic persistently infected domestic cats (2). Interestingly, the association of imidocarb dipropionate and doxycycline seems to eliminate Cytauxzoon sp. erythroparasitemia in cat no. 1. We could not exclude spontaneous elimination of the parasite or very low parasitemia undetectable by PCR analysis after therapy. In fact, very low levels of parasite DNA may result in inconsistent PCR results (2). Further studies need to assess if treatment is needed in this infection and the type of adequate treatment protocol for parasite cure.

The two cats reported in the present study were 6 and 7 months old at the time of diagnosis and belonging to same litter. The way of transmission of Cytauxzoon sp. is unknown. Tick bite is the most likely way of transmission, as occurs in C. felis infection in cats (18). However, vertical transmission of this infection might be considered, based on the young age of both cats of the same litter. Interestingly, Cytauxzoon sp infection was previously reported mainly in young adult cats (7). Moreover, fatal cytauxzoonosis by $C$. felis was described in a free-ranging bobcat cub of approximately 2-3 months (14), and a seven years old C. felis-infected kitten was identified in a study involving Florida panthers and Texas cougars (19). In contrast, lack of evidence for perinatal transmission of $C$. felis in domestic cats was reported (20). Further studies need to investigate possible ways of transmission for this new emergent infection in cats.

\section{CONCLUSION}

In conclusion, infection by Cytauxzoon sp. is present in Italy in the northeastern part of the peninsula but also in the central part in domestic cats. One of the two young cats described appeared to clear up the infection after therapy, while the other presented with persistent erythroparasitemia, suggesting a role as a reservoir in domestic cats as an alternative host to wild felids in the life cycle of this parasite.

Peer-review: Externally peer-reviewed.

Author Contributions: Concept - C.E., L.S.G.; Design - C.E.; Supervision - L.S.G., P.M., F.T.; Funding - C.M.; Materials - E.B., 
C.E., M.T.; Data Collection and/or Processing - E.B., C.E., M.T.; Analysis and/or Interpretation - C.E., L.S.G., M.T.; Literature Review - C.E.; Writing - C.E., L.S.G., M.T.; Critical Review - C.E., L.S.G., T.F., M.C., M.P.

Acknowledgements: The authors are grateful to the San Marco laboratory staff especially to Dr. Martina Nicetto for molecular technical support.

Conflict of Interest: No conflict of interest was declared by the authors.

Financial Disclosure: The authors declared that this study has received no financial support.

Hakem değerlendirmesi: Dış bağımsız.

Yazar Katkıları: Fikir - C.E., L.S.G.; Tasarım - C.E.; Denetleme L.S.G., P.M.; Kaynaklar - C.M.; Malzemeler - E.B., C.E., M.T.; Veri Toplanması ve/veya İşlemesi - E.B., C.E., M.T.; Analiz ve/veya Yorum - C.E., L.S.G., M.T.; Literatür Taraması - C.E.; Yazıyı Yazan - C.E., L.S.G., M.T.; Eleştirel inceleme -C.E., L.S.G., T.F., M.C., M.P.

Teşekkür: Yazarlar San Marco laboratuarı çalışanlarına, başta Dr. Martina Nicetto'ya teknik moleküler desteğinden ötürü teşekkür eder.

Çıkar Çatışması: Yazarlar çıkar çatışması bildirmemişlerdir.

Finansal Destek: Yazarlar bu çalışma için finansal destek almadıklarını beyan etmişlerdir

\section{REFERENCES}

1. Meinkoth $\mathrm{JH}$, Kocan AA. Feline cytauxzoonosis. Vet Clin North Am Small Anim Pract 2005; 35: 89-101. [CrossRef]

2. Brown HM, Latimer KS, Erikson LE, Cashwell ME, Britt JO, Peterson DS. Detection of persistent Cytauxzoon felis infection by polymerase chain reaction in three asymptomatic domestic cats. J Vet Diagn Invest 2008; 20: 485-8. [CrossRef]

3. Ketz-Riley CJ, Reichard MV, Van den Bussche RA, Hoover JP, Meinkoth J, Kocan AA. An intraerythrocytic small piroplasm in wild-caught Pallas's cats (Otocolobus manul) from Mongolia. J Wildl Dis 2003; 39: 424-30. [CrossRef]

4. Criado-Fornelio A, Gónzalez-del-Río MA, Buling-Saraña A, BarbaCarretero JC. The "expanding universe" of piroplasms. Vet Parasitol 2004; 119: 337-45. [CrossRef]

5. Luaces I, Aguirre E, Garcia-Montijano M, Velarde J, Tesouro MA, Sanchez C, et al. First report of an intraerythrocytic small piroplasm in wild Iberian lynx (Lynx pardinus). J Wildl Dis 2005; 41: 810-5. [CrossRef]
6. Criado-Fornelio A, Buling $A$, Pingret $J \mathrm{~L}$, Etievant $\mathrm{M}$, BoucrautBaralon C, Alongi A, et al. Hemoprotozoa of domestic animals in France: prevalence and molecular characterization. Vet Parasitol 2009; 159: 73-6. [CrossRef]

7. Carli E, Trotta $M$, Chinelli $R$, Drigo $M$, Sinigoi $L$, Tosolini $P$, et al. Cytauxzoon sp. infection in the first endemic focus described in domestic cats in Europe. Vet Parasitol 2012; 183: 343-52. [CrossRef]

8. Sanger F, Nicklen S, Coulson AR. DNA sequencing with chain-terminating inhibitors. Proc Natl Acad Sci U S A 1977; 74: 5463-7. [CrossRef]

9. Willi B, Boretti FS, Baumgartner C, Tasker S, Wenger B, Cattori V, et al. Prevalence, risk factor analysis, and follow-up of infections caused by three feline hemoplasma species in cats in Switzerland. J Clin Microbiol 2006; 44: 961-9. [CrossRef]

10. Anderson B, Sims K, Regnery R, Robinson L, Schmidt MJ, Goral S, et al. Detection of Rochalimaea henselae DNA in specimens from cat scratch disease patients by PCR. J Clin Microbiol 1994; 32: 942-8.

11. Solano-Gallego L, Rodriguez-Cortes A, Trotta M, Zampieron C, Razia L, Furlanello T, et al. Detection of Leishmania infantum DNA by fret-based real-time PCR in urine from dogs with natural clinical leishmaniosis. Vet Parasitol 2007; 147: 315-9. [CrossRef]

12. Decaro N, Elia G, Martella V, Campolo M, Desario C, Camero M, e al. Characterization of the canine parvovirus type 2 variants using minor groove binder probe technology. J Virol Methods 2006; 133: 92-9. [CrossRef]

13. Stockham ST, Scott MA. Erythrocytes. In: Stockham ST, Scott MA editors. Fundamentals of veterinary clinical pathology. 1st ed. Ames: Blackwell publishing; 2002. p. 85-154.

14. Nietfeld JC, Pollock C. Fatal cytauxzoonosis in a free-ranging bobcat (Lynx rufus). J Wildl Dis 2002; 38: 607-10. [CrossRef]

15. Cohn LA, Birkenheuer AJ, Brunker JD, Ratcliff ER, Craig AW. Efficacy of atovaquone and azithromycin or imidocarb dipropionate in cats with acute cytauxzoonosis. J Vet Intern Med 2011; 25: 55-60. [CrossRef]

16. Greene CE, Latimer K, Hopper E, Shoeffler G, Lower K, Cullens F. Administration of diminazene aceturate or imidocarb dipropionate for treatment of cytauxzoonosis in cats. J Am Vet Med Assoc 1999; 215: 497-500.

17. Lewis KM, Cohn LA, Marr HS, Birkenheuer AJ. Diminazene diaceturate for treatment of chronic Cytauxzoon felis parasitemia in naturally infected cats. J Vet Intern Med 2012; 26: 1490-3. [CrossRef]

18. Reichard MV, Edwards AC, Meinkoth JH, Snider TA, Meinkoth KR, Heinz RE, et al. Confirmation of Amblyomma americanum (Acari: Ixodidae) as a vector for Cytauxzoon felis (Piroplasmorida: Theileriidae) to domestic cats. J Med Entomol 2010; 47: 890-6. [CrossRef]

19. Rotstein DS, Taylor SK, Harvey JW, Bean J. Hematologic effects of cytauxzoonosis in Florida panthers and Texas cougars in Florida. $J$ Wildl Dis 1999; 35: 613-7. [CrossRef]

20. Lewis KM, Cohn LA, Marr HS, Birkenheuer AJ. Lack of evidence for perinatal transmission of Cytauxzoon felis in domestic cats. Vet Parasitol 2012; 188: 172-4. [CrossRef] 